\title{
Parenting an Autistic Child: A Qualitative Study
}

\section{Aysel Topan, PhD, MSc, $R N^{1^{*}}$, Serap Demirel, MSc, $R N^{2}$, Işin Alkan, MSc, $R N^{1}$, Tülay Kuzlu Ayyildiz, $P h D, M S c, R N^{1}$ and Sevda Doğru, MSc, $R N^{2}$}

${ }^{1}$ Department of Nursing, Faculty of Health Sciences, Zonguldak Bülent Ecevit University, Zonguldak, Turkey

${ }^{2}$ Department of Nursing, Institute of Health Sciences, Zonguldak Bülent Ecevit University, Zonguldak, Turkey

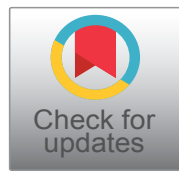

*Corresponding author: Aysel Topan, PhD, MSc, RN, Assistant Professor, Department of Nursing, Faculty of Health Sciences, Zonguldak Bülent Ecevit University, Zonguldak, Turkey, Tel: 00-90-372-261-33-93

\begin{abstract}
To determine feelings and thoughts of parents with autistic children. This qualitative study consisted of 20 parents. 'Personal Information Form' and semi-constituted 'Guide Interview Form' with qualitative face-to-face technique were used. Thematic analysis method was used for analyses. The mean age of children was $10.80 \pm 4.30$ (3-16 year-olds). Expressions of parents were grouped under the following main themes: Feelings of parents when they learnt about the disease, how this condition affected the life quality of parents, problems of parents about childcare, and concerns of parents regarding the future of their children. Parents expressed their feelings upon learning about the disease: 'I felt unhappy, shocked, extremely upset and I could not accept this situation'. Their social and family life was negatively affected, and they were disturbed due to gaze of others. Needs of families and children should be met, different perspectives should be developed with a common philosophy.
\end{abstract}

\section{Keywords}

Autistic child, Thoughts of parents, Support, Qualitative study

\section{Point of Interest}

1. Life of families are negatively affected, and they need financial and moral support.

2. Families need especially nurses, social service experts, doctors and other professional healthcare services.

3. Healthcare professionals must be educated with respect to the necessity of parents, increasing their coping skill.

4. Early education programs applied to the children with special needs should be re-evaluated in Turkey.

\section{Introduction}

Common developmental disorders (CDD) are neuropsychiatric disorders that generally emerges in the first years of life and characterized by a delay or deviation in social relationships, communication and cognitive development. Autism, seen in childhood ages, is a disorder including significant problems in social interaction and language development [1].

Autism, included among autism spectrum disorders (ASD) and previously considered as a psychogenic disease, is now addressed as a neuro-developmental disease with a genetic basis in which abnormal brain development is observed [2]. Autism is a deficiency with a neuro-biological origin emerging before threeyears-old and negatively affecting social interaction, communicational skills and other cognitive functions of the individuals [3]. Autism spectrum disorder is observed among boys four times more than girls, and its incidence is one in 150 children [4]. Although clinical symptoms are present around three-years-old, typical language development may delay differentiation of the symptoms [5]. Intelligence scores vary between significantly low and more than average, and mental retardation is in question in nearly $70 \%$ of the cases [6].

It has been postulated that autism has a heterogeneous etiology. Among potential etiological factors, there are some genetic, biochemical, neuroanatomical, familial and environmental factors. Considering familial factors, it was observed that parents of children have an obsessive personal characteristics, a high cultural and socio-economic level, a personality that

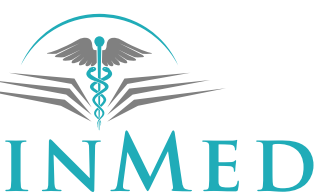


does not allow them to establish a sufficient emotional relationship with their children and a dull spiritual structure; and especially their fathers present with schizoid personal characteristics. These studies mostly focus on broad autism phenotype [6].

Knowledge level of the community about autism is quite low and it is mostly equated to mental retardation [3]. However; since it is well known that its incidence has increased all over the world within the last 50 years, it is required to pay attention. Early diagnosis, treatment and education are important for the individuals suffering from this disorder. It is not possible to completely mitigate the difficulties caused by this disorder with the alternatives present today, but symptoms may be alleviated with versatile treatment strategies [7]. Practices and techniques that are introduced for the individuals with a diagnosis of autism generally aim to make a contribution to independent lives of these individuals by focusing on teaching skills in the areas such as social development, language development, nonverbal communication, playing and behavior management in which these individuals are insufficient [8].

The most important and smallest system of the community is family [9]. Family is one of the environments having the most effective role in the development and education of the child. Joining of a baby to the family is a condition that changes the existing dynamics and living of the families. Families enter into an adaptation period for this new condition; and this period can be quite difficult and distressing for all family members, particularly mothers, especially if the baby has some special requirements. Parents may experience sadness, obscurity, crying, confusion, inability to accept, shock, helplessness, anxiety and frustration, especially when they first hear the diagnosis [10-12].

The diagnosis of autism for the child may affect the whole life of the family and cause stress in the family members. Parenting an autistic child can have a negative impact on the psychological state of the family, especially by causing problems in the mother's working life and social relations [13-16]. Families may need educational, psychological and social support for themselves and their children, and may have difficulties in overcoming the families' negative attitudes towards autism. A highly tough adaptation period is in question especially for the families of the autistic individuals with the specific difficulties of the autism (for instance; intense behavioral problems). During this period, family members try to cope with some negative feelings such as intense anxiety, burnout and future concerns and various problems (for example; seeking for educational support, explaining ASD to the environment) [17].

This study was performed qualitatively to reveal thoughts, feelings and problems of the families having autistic children.

\section{Materials and Methods}

The study was qualitative-type and carried out in private educational institutions in Zonguldak City. The universe of the study was composed of parents living in Zonguldak and having at least one autistic child. Sample of the study included 20 parents of various education level, social and economic characteristics in accordance with the principle of "data saturation".

Data were collected by one-to-one interviews performed with the parents voluntary participated in the study through "Personal Information Form" and semi-structured "Guide Interview Form". "Personal Information Form" included sociodemographic characteristics of the parents included in the study (age, education levels, occupations, socioeconomic status, number of children, marital status, kinship status, family type) and some features such as sex and age of the diagnosis of the autistic child. Moreover, semi-structured "Guide Interview Form" that was prepared to lead and guide the interview was used in accordance with the flow of the interview without following a specific order. Interviews were started with the questions such as "What did you feel when you first heard that your child was autistic? How did the health problem of your child affect your life or how is it affecting?" "What have changed in your life after the diagnosis of your child?". Topics that were underlined and in which the nurses told the interview process and its content were determined. The interviewer tried to explain the topics in detail by using appropriate communication techniques in order to clarify some topics.

Interviews were performed in parent's room of the private education school. This room was preferred since it was the room in which individual teacher-parent interviews are made, parents do not feel as foreign, they feel themselves comfortable and safe and it was silent environment with nobody in. In this way, an environment was provided in which parents could give accurate, complete and sincere answers during the interviews.

At first, the aim of the interview was explained in the environment in which the interview would be performed. Parents were informed about the possible duration and confidentiality of the interviews and their consents were taken. Personal information forms were completed by the parents before starting interviews. During the interviews, parents were provided to explain their thoughts in detail by qualitative interview principles. Observational notes were taken for the answers and the behaviors of the parents in order not to interrupt communication with the parents. The interviews performed with each parent lasted for nearly 2030 minutes. All interviews were terminated when similar statements were repeated (20 parents). 


\section{Data Analysis}

Stage 1: Each interview was typed (four interviews which are not daily recorded on the same day, the recorded ones in two days). Data coding, the first phase of content analysis, was done to the typed interviews. For data coding:

- Written statements of the participants were read again and again.

- The meaning of each statement of the participants was determined.

- Descriptive names/codes were given to these statements which had specified meanings.

- Similar codes in distinct parts of the interviews were associated with each other and brought together.

- A code list was generated after coding all these data in this way.

Stage 2: In this stage, the themes were created with the following steps:

- Draft themes were crated with re-evaluating the similarities and differences among the codes exposed and assembled in the first stage.

- A pediatric nurse except the researcher created individually the codes and themes for data validity. Following this, the researchers gathered to evaluate the relationship between codes and themes, and the themes were reformed.

The last evaluation of themes was done by two experts in the field of pediatric nursing with respect to the validation of coherence between the themes and the codes under themes (interior validation).

The quantitative data was evaluated by SPSS 19.00 software using number, percentage and arithmetic mean.

Numbers, percentages and arithmetic mean were used in the analysis of quantitative data.

\section{Results}

According to the Table 1, mean age of the mothers was $39.8 \pm 7$-years-old, and mean age of the fathers was found to be $42 \pm 7$-years-old. It was detected that $45 \%$ of the mothers $(n=9)$ and $15 \%$ of the fathers $(n=3)$ in the study group were graduates of elementary school; $85 \%$ of the mothers $(n=17)$ were housewives and $85 \%$ of the fathers $(n=17)$ were unemployed.

Theme 1: Feelings of the parents when they first heard about this condition (autism) of the child (Table 2 ): While most of the parents in the study stated that they felt very unhappy when they learned that their child was autistic, some parents stated that they did not know anything about autism, they thought that it was a temporary condition and some parents experienced
Table 1: Sociodemographic characteristics of the parents.

\begin{tabular}{|c|c|c|}
\hline Characteristics & $\mathbf{n}$ & $\%$ \\
\hline $\begin{array}{l}\text { Education status of the mother } \\
\text { Illiterate } \\
\text { Elementary school } \\
\text { Middle school } \\
\text { High school } \\
\text { University }\end{array}$ & $\begin{array}{l}1 \\
9 \\
2 \\
5 \\
3\end{array}$ & $\begin{array}{l}5.0 \\
45.0 \\
10.0 \\
25.0 \\
15.0\end{array}$ \\
\hline $\begin{array}{l}\text { Education status of the father } \\
\text { Illiterate } \\
\text { Elementary school } \\
\text { Middle school } \\
\text { High school } \\
\text { University }\end{array}$ & $\begin{array}{l}0 \\
3 \\
1 \\
9 \\
7\end{array}$ & $\begin{array}{l}0 \\
15.0 \\
5.0 \\
45 \\
35\end{array}$ \\
\hline $\begin{array}{l}\text { Occupation of the mother } \\
\text { Housewife } \\
\text { Officer } \\
\text { Worker } \\
\text { Freelancer } \\
\text { Retired }\end{array}$ & $\begin{array}{l}17 \\
2 \\
0 \\
0 \\
1\end{array}$ & $\begin{array}{l}85.0 \\
10.0 \\
0 \\
0 \\
5.0\end{array}$ \\
\hline $\begin{array}{l}\text { Occupation of the father } \\
\text { Unemployed } \\
\text { Officer } \\
\text { Worker } \\
\text { Freelancer } \\
\text { Retired }\end{array}$ & $\begin{array}{l}1 \\
6 \\
5 \\
6 \\
2\end{array}$ & $\begin{array}{l}5.0 \\
30.0 \\
25.0 \\
30.0 \\
10.0\end{array}$ \\
\hline $\begin{array}{l}\text { Socioeconomic status } \\
\text { Income is less than the expenses } \\
\text { Income is equal to the expenses } \\
\text { Income is more than the expenses }\end{array}$ & $\begin{array}{l}1 \\
15 \\
4\end{array}$ & $\begin{array}{l}5.0 \\
75.0 \\
20.0\end{array}$ \\
\hline $\begin{array}{l}\text { Number of children } \\
1 \\
2 \\
3 \text { and more }\end{array}$ & $\begin{array}{l}5 \\
12 \\
3\end{array}$ & $\begin{array}{l}25.0 \\
60.0 \\
15.0\end{array}$ \\
\hline $\begin{array}{l}\text { Kinship status } \\
\text { Yes } \\
\text { No }\end{array}$ & $\begin{array}{l}5 \\
15\end{array}$ & $\begin{array}{l}25.0 \\
75.0\end{array}$ \\
\hline $\begin{array}{l}\text { Family type } \\
\text { Core } \\
\text { Large family } \\
\text { Broken family }\end{array}$ & $\begin{array}{l}16 \\
2 \\
2\end{array}$ & $\begin{array}{l}80.0 \\
10.0 \\
10.0\end{array}$ \\
\hline $\begin{array}{l}\text { Marital status } \\
\text { Married } \\
\text { Divorced }\end{array}$ & $\begin{array}{l}18 \\
2\end{array}$ & $\begin{array}{l}90.0 \\
10.0\end{array}$ \\
\hline Total & 20 & 100.0 \\
\hline
\end{tabular}

Table 2: Themes obtained following the interviews.

\section{Theme}

1. The feelings of the parents when they first heard about this condition (autism) of the child

2. How this condition of the child affected the lives of their parents

3. What kind of problems parents experienced during the care of their children

4. Concerns of the parents regarding their children 
feelings as they were shocked, collapsed and they did not get it for their child. Some of these statements are given below.

- $\quad$ This condition affected us very badly. Especially my wife was very worried. We got information about autism when we searched for the reasons of his inability to speak and of his such behaviors. I made a speech by gathering all family members, I told that we could cope with this condition together. This speech had a relaxing effect on the family. (FATHER 2, 58-years-old, 3 children).

- At first, I was not affected by the condition so much. Then we began to a private education school. The teacher in the school told that my child was so slow. At that time, I felt very miserable. I was so sad. (MOTHER 4, 35-years-old, 2 children).

- I was so much affected by this condition at first. Even I could not accept; I said "this is impossible" when I first heard and I thought that I was alone. (MOTHER 5, 47-years-old, 1 child).

- When I first heard, I thought that it was a misdiagnosis. Therefore, we visited different doctors. It was maybe we could not accept it. (MOTHER 7, 42-years-old, 2 children).

- When I was first told, I felt so sad. We were destroyed. I could not get it for my child in any way. Even we visited hodjas. The doctor we recently saw told us that there are many hope mongers around and we do not need to visit more and more doctors. He said that all he needs is education. (MOTHER 16, 40-years-old, 2 children).

- I cried a lot. I was destroyed. My husband always told me that there was no problem and he would get well. But I accepted the situation when it did not change this year. Again, I was so worried and cried a lot. (MOTHER 18, 40-years-old, 2 children).

Theme 2: How this condition of the child affected the lives of their parents (Table 2): More than half of the parents stated that they did not have a social life, they could not go out of home outside their needs and they gave up their ideals for the future. Parents also declared that there were abduction and discussions within the family due to the autistic child, and even their close relatives stayed away from themselves.

- We can go everywhere with him, he loves us; even he is envying us from the others, maybe he does not wanna share us. Previously, people around were looking strangely but they started to behave moderately when we said "come on and talk to Gokhan". (FATHER 2, 58-years-old, 3 children).

- I feel embarrassed when we are outside and my child plays with everything; therefore, we do not go out so often. Especially my father-in-law helps me too much; he is inspiring us by saying "why are you sad? He will get well soon". His uncle takes care of my other son; he sometimes envies him. He gets spoiled and feels happy when he sees our relatives. He is swinging on the hammock at home. His problems become more severe when he gets sick. (MOTHER 4, 35-years-old, 2 children).

- Neither our day nor our night is clear. We cannot go to see people. He suddenly hits his head on the walls. He bites us or himself. He suddenly starts crying. He is continuously escaping. (MOTHER 10, 42-years-old, 1 child).

- We do not have a social life. Our child is in the center of our family. We live our whole life according to him. His sister is also helping (5-years-old). His uncle told me with an instant anger that it was because of me; he then regretted, embarrassed but it suddenly came out of his mouth (FATHER 11, 42-years-old, 2 children).

- He caused problems within the family. My husband did not believe that it was autism. He stayed unresponsive when the doctor clearly stated that it was autism. He did not pay attention. He began to stay away from me and the child. He cheated on me and we divorced. I got psychological support for a long time. My son is my whole world. It is great if I can go outside once a week. My mother is living close but she cannot help me so much. I cannot see anyone. (MOTHER 12, 29-yearsold, 1 child).

- It is affecting negatively. We feel excluded. We have difficulty; he may become guilty when he is not. It is very hard to say "don't". When he wants something, he wants it to happen immediately, he shouts and becomes bad-tempered. When something was bought, he wants us to buy the same thing to his twin; he likes sharing with his brother. His brother is very jealous of him. He gets ill-tempered and thinks that we love Emirhan but not him as much. (MOTHER 15, 47-years-old, 5 children).

Theme 3: What kind of problems parents experienced during the care of their children (Table 2): Some of the parents stated that they experienced difficulties especially about toilet education in meeting self-care needs of their children. Some parents declared that they had difficulties during providing care since they showed aggressive behaviors while their self-care needs were met.

- When he wants something, he never takes it himself; he always wants from me. In general, he tells what he wants by sign language. He gets mad if his wishes do not come true, he hits me and he throws me the thing he has in his hand. I do not have any difficulties except these; I can cope with patience and education. (MOTHER 1, 27-years-old, 1 child).

- Since I always go to education center, my daughter llayda is staying with her aunt. She is saying: "You don't love me, you are always leaving me to my aunt. While I take care of Ihsan, her father is taking care of her; therefore, she feels more close to her father. She 
says that she loves her father much more. (MOTHER 3, 45-years-old, 2 children).

- Yes, we live. It is necessary to be faithful and this is a condition that requires too much patience. It is necessary to speak clearly and tough during his care. We experience problems if we tolerate and don't provide that balance, we experience problems. We said that we had one child and we behaved very softly but we were wrong; there should be no place for compromises in the education. (FATHER 11, 42-years-old, 2 children).

- I do not experience too many problems in the care. I can have success in their education if I focus and continue persistently. He can eat his meal himself. He can also dress up himself. He can handle his needs for toilet. (MOTHER 12, 29-years-old, 1 child).

- I sometimes experience problems. I got the biggest support from my daughters. They cleaned up and fed. I could not live without them. It was preterm delivery, they were premature and their need for care was too much. (MOTHER 15, 47-years-old, 5 children).

Theme 4: Concerns of the parents regarding their children (Table 2): Most of the parents expressed some concerns such as what would happen to their autistic children, who would take care of them and how they continue their lives if something bad happens to them.

- My biggest fear is who will take care of him when we die? (mother is crying). I think that my husband will not take care of him as much as I do. (MOTHER 3, 45-years-old, 2 children).

- Inevitably one can have concerns. I cannot stand without asking to myself as how he will continue his life and who will take care of him if something happens to him. (MOTHER 6, 33-years-old, 2 children).

- Yes. The question of "who will take care of our child when we die?" scares us. Sometimes I wish to die together in an accident. (MOTHER 8, 46-years-old, 1 child).

- He has his grandmother, me and his uncle; thus we are not afraid. At least one of us will take care of him. We wish neither such a child nor money from the God; it is so difficult. (MOTHER 10, 42-years-old, 1 child).

- No future concerns. Our only goal is to have him recovered. The most important is that he can become self-sufficient. We try to make him sustain his life himself. We try to save some money for the future. (FATHER 11, 42-years-old, 2 children).

- I am very afraid; who will take care of my child when I'm gone? There is no husband, no grandmother, and no sibling. (MOTHER 12, 29-years-old, 1 child).

- I have no fears. (she believes that it will resolve by education), we would like to send him to kindergarten, I think that she will get relaxed. (family gives a huge support.) (MOTHER 13, 32-years-old, 1 child).

\section{Discussion}

While most of the parents in the study stated that they felt very unhappy when they learned that their child was autistic, some parents stated that they did not know anything about autism, they thought that it was a temporary condition and some parents experienced feelings as they were shocked, collapsed and they did not get it for their child.

Although some parents included in the study have stated that they know nothing about autism and thought that it was a temporary condition, majority of them expressed feelings such as intense unhappiness, confusion, sadness, disappointment, non-acceptance and shock. Families have declared the concern of inability to know what to do. The reason of all these feelings might be the fear they have against the unknown. The study by Üstüner-Top [17] reported that families expressed the feelings of sadness, disappointment and fear when they were first diagnosed with autism. In the study by Bilgin and Kucuk [10], almost half of the mothers declared that they had concerns about autistic child and they experienced stress. They stated that they became miserable, they did not know how to cope with this situation and thought that it was a treatable condition. However; they declared that they felt very bad when they learned that it was not a temporary condition and it had difficulties. Most of the mothers told that they could not accept this situation at the first time, but they began to accept it as they met the families of other autistic children in the education centers. In their study with the parents of 50 autistic children, Gürel-Selimoğlu, Özdemir, Töret and Özkubat [18] reported that families expressed emotional states such as deep sadness, obscurity, crying, confusion, non-acceptance, shock, despair and anxiety when their children were first diagnosed with autism. There are similar studies in the literature and in these studies, families expressed shock, non-acceptance, denial and pessimistic thoughts when diagnosis was first made $[11,19,20]$.

In this study, almost all families indicated that having a child with autism spectrum disorder has negatively affected their lives, they needed to spend time with their children more than necessary, they needed to undertake more personal time and responsibilities with their autistic children and this situation led to negativity in their family relationships and especially their social lives. In the study by Güleç-Aslan, Cihan and Altin [12], families of the child with autism spectrum disorder have associated the responsibilities that living with autism spectrum disorder brought especially to the mothers and the limitations in social life. In the study by Bilgin and Kucuk [10], it was reported that lives of the mothers have completely changed during this long period and their social lives were interrupted. The study by Dyches, Wilder, Sudweeks, Obiakor and 
Algozzine [20] also reported that families of autistic children experienced stigmatization in each areas of life. Dale, Jahoda and Knott [21] have emphasized that mothers feeling a personal responsibility about their autistic children were more stressful. Whitaker [22] indicated that their difficulties in adaptation and their psychological problems might increase when they perceived autism as an ongoing problem which cannot be changed and controlled. Dillenburger, Keenan, Doherty, Byrne and Gallagher [23] have declared that some of the families were under intense stress, they were completely away from social life due to the behaviors of autistic child and some of them forgot to be a family because of dealing with the autistic child.

Similar studies in the literature showed that establishment of whole life on the autistic child and limiting of social life by the families, especially by their mothers, have negatively affected psychological state of the mothers [13,22-24].

Bircan [14] reported that parents could not take time for themselves and for their other children due to the difficult and long nature of care for autistic child; and it was emphasized that families encountered economic, emotional, familial and environmental problems while raising an autistic child. In the study, it was shown that families did not have a social life and even they were isolated from social life. Hastings [15] reported that behavioral problems of the autistic child made their parents more distressed and this situation increased behavioral problems of autistic children as the parents became stressed. Hastings, Kovshoff, Ward, Degli Espinosa, Brown and Remington [16] stated that mothers of an autistic child were more stressed and depressive compared to the fathers. Cavkaytar, Ceyhan, Adiguzel and Uysal [25] indicated that social and emotional states and life cycles of the families were directly affected with the autistic child, and this situation led them to feel insufficient in parenting skills.

Although most of the mothers told that they experienced problems during the care of their child, there were also mothers declaring that they experienced no problems. It was concluded that mothers overcame these difficulties with education and besides, having other people helping at home was important. Mothers, who told that they experienced problems, stated that it was in self-care and education. The study by Görgü [9] reported that most of the families having an autistic child have taken emotional and social support and had knowledge about the autistic child. In their study with the mothers of 43 autistic children, Bilgin and Kucuk [10] reported that $44 \%$ of the mothers had many difficulties about care and could not get enough support from their husbands. Gürel-Selimoğlu, Özdemir, Töret and Özkubat [18] have reported in their study that families indicated that they could not get sufficient psychological and financial support, they were not provided educational support and they could not get enough information about autism from the authorized people (Doctors, Guidance and Research Centers, etc.). In the study by DeGrace [24], parents declared that each second they spent with their children for the care activities such as bathing, dressing and teeth brushing was very intense. Mothers stated that this condition was sometimes incredibly difficult, and they needed to spend almost all their lives for autistic children and this condition was severely stressful and complicated. In the study by Bircan [14], it was reported that families did not get professional help from relevant social service experts for the autistic child during care period, social service experts did not have sufficient knowledge about their roles and tasks and families tried to solve this problem themselves. Weiss [26] reported that social and educational support given to the families created positive effects on stress although limited financial opportunities and insufficient service support negatively affected prognosis. In the study by Biçak [27], it was reported that families did not hear anything about autism before the diagnosis, they did not know what to do; thus, they needed information about what they would do themselves about autism. In the study by Akayildiz and Sariçam [28], it was shown that mean social anxiety and social avoidance scores of the parents of autistic children were found to be higher compared to the parents of healthy children; and mean social anxiety and social avoidance scores of women were higher compared to men.

Most of the parents included in the study reported that they did not know what would happen to their child if something happened to them and thought that nobody would take care of them; and they reported their concerns and fears about how their children would continue their lives. Fears of the parents can be explained by the fact that they cannot get sufficient help even when they are alive, and they think that nobody will take care of their children adequately after something happens to them.

There are some studies in the literature similar to our findings. In the previous studies, it was reported that family members and particularly mothers of children with a diagnosis of autism spectrum disorder experienced negative feelings such as anxiety and concerns about the future of their children $[21,23,29,30]$.

\section{Conclusions}

Finally, families have expressed feelings such as intense sadness, obscurity, crying, confusion, non-acceptance, shock, despair and anxiety. Almost all of them stated that their lives were negatively affected, and they experienced problems derived from the lack of financial-moral support during caring period. Most of the families expressed their concerns about the future of their children. The results of this study show that early education programs applied to the 
children with special needs should be re-evaluated in Turkey. Families need especially nurses, social service experts, doctors and other professional healthcare services. These healthcare professionals should be educated about the necessity of shaping parent-focused supports and introducing these services to the parents in order to increase support resources of parents and their coping skills.

\section{Funding}

This research did not receive any specific grant from funding agencies in the public, commercial, or not-forprofit sectors.

\section{Disclosure Statement}

No potential conflict of interest was reported by the authors.

\section{References}

1. Karabekiroğlu K, Cakin-Memik N, Ozcan-Ozel O, Toros F, Öztop D, Özbaran B, et al. (2009) DEHB ve Otizm ile İlgili Bilgi Düzeyleri ve Damgalama: Sinif Öğretmenleri ve Anababalarla Çok Merkezli Bir Çalişma. Klinik Psikiyatri Dergisi 12: 79-89.

2. Özbaran B (2014) Do environmental factors have influence on autism spectrum disorder? J Pediatr Res 1: 170-173.

3. Yanardağ M, Yilmaz I (2012) Otistik bozukluk gösteren çocuklarda bir müdahale yaklaşimi: Su içi etkinlikler. International Journal of Early Childhood Special Education 4: 32-45.

4. Karaarslan Ö, Kutlu M (2015) Otizm Spektrum Bozukluğu Olan Bireylerde Sosyal Öykü Kullanmi. Çukurova Üniversitesi Sosyal Bilimler Enstitüsü Dergisi 19: 1-17.

5. Tural-Hesapçioğlu S, Göker Z, Bilginer Ç, Kandil S (2012) Otizm Spektrum Bozukluğu Bulunan Olgularin Otizm Şiddetleri, Psikososyal ve Bilişsel Özellikleri Açisindan Değerlendirilmesi. New Symposium Journal 50: 237-242.

6. Uğur Ç (2013) Otizm spektrum bozukluklarinda vitamin D düzeyleri. Ankara University, Ankara, Turkey.

7. Şener EF, Özkul Y (2013) Otizmin genetik temelleri. Sağlik Bilimleri Dergisi 22: 86-92.

8. Olçay-Gül S, Tekin-Iftar E (2012) Otizm spektrum bozukluğu tanisi olan bireyler için sosyal öykülerin kullanimi. Ankara Üniversitesi Eğitim Bilimleri Fakültesi Özel Eğitim Dergisi 13: 1-24.

9. Görgü E (2005) 3-7 Yaş arasi otistik çocuğu olan annelerin algiladiklari sosyal destek. Marmara University, İstanbul, Turkey.

10. Bilgin H, Kucuk L (2010) Raising an autistic child: Perspectives from Turkish mothers. J Child Adolesc Psychiatr Nurs 23: 92-99.

11. Sivberg B (2002) Coping strategies and parental attitudes, a comparison of parents with children with autistic spectrum disorders and parents with non-autistic children. Int J Circumpolar Health 61: 36-50.

12. Güleç-Aslan $Y$, Cihan H, Altin D (2014) Living with a child with autism spectrum disorders: Experiences of mothers. Electronic Journal of Social Sciences 13: 962014111.

13. Twoy R, Connolly PM, Novak JM (2007) Coping strategies used by parents of children with autism. J Am Acad Nurse Pract 19: 251-260.
14. Bircan GA (2004) Otistik çocuğa sahip ailelerin aile işlevlerinin incelenmesi. Hacettepe University, Ankara, Turkey.

15. Hastings RP (2002) Parental stress and behaviour problems of children with developmental disability. Journal of Intellectual and Developmental Disability 27: 149-160.

16. Hastings RP, Kovshoff $H$, Ward NJ, Degli Espinosa $F$, Brown T, et al. (2005) Systems analysis of stress and positive perceptions in mothers and fathers of pre-school children with autism. J Autism Dev Disord 35: 635-644.

17. Üstüner-Top F (2009) Otistik çocuğa sahip ailelerin yaşadiklari sorunlar ile ruhsal durumlarinin değerlendirilmesi: Niteliksel araştirma. Çocuk Dergisi 9: 34-42.

18. Gürel-Selimoğlu Ö, Özdemir S, Töret G, Özkubat U (2013) Otizmli çocuğa sahip ebeveynlerin otizm tanilama sürecinde ve tani sonrasinda yaşadiklari deneyimlerine ilişkin görüşlerinin incelenmesi. International Journal of Early Childhood Special Education 5: 129-167.

19. Benson PR (2006) The impact of child symptom severity on depressed mood among parents of children with ASD: The mediating role of stress proliferation. J Autism Dev Disord 36: 685-695.

20. Dyches TT, Wilder LK, Sudweeks RR, Obiakor FE, Algozzine B (2004) Multicultural issues in autism. J Autism Dev Disord 34: 211-222.

21. Dale E, Jahoda A, Knott F (2006) Mothers' attributions following their child's diagnosis of autistic spectrum disorder: Exploring links with maternal levels of stress, depression and expectations about their child's future. Autism 10: 463479.

22. Whitaker $P$ (2002) Supporting families of preschool children with autism: What parents want and what helps. Autism 6: 411-426.

23. Dillenburger K, Keenan M, Doherty A, Byrne T, Gallagher S (2010) Living with children diagnosed with autism spectrum disorder: Parental and professional view. British Journal of Special Education 37: 13-23.

24. DeGrace BW (2004) The everyday occupation of families with children with autism. Am J Occup Ther 58: 543-550.

25. Cavkaytar A, Ceyhan E, Adiguzel OC, Uysal H (2014) Effectiveness of online information and support services on the education of parents of children with intellectual disability. DADD Online Journal.

26. Weiss MJ (2002) Hardiness and social support as predictors of stress in mothers of typical children, children with autism, and children with mental retardation. Autism 6: 115130.

27. Biçak N (2009) Otizmli çocuklarin annelerinin yaşadiklarinin belirlenmesi. Abant İzzet Baysal University, Bolu, Turkey.

28. Akayildiz K, Sariçam A (2015) Otizm Spektrum Bozukluğu Olan Çocuğa Sahip Ebeveynler ile Normal Çocuğa Sahip Ebeveynlerin Sosyal Kaygi ve Sosyal Kaçinma Düzeylerinin Karşilaştirilmasi. 25 Ulusal Özel Eğitim Kongresi, İstanbul (Turkey).

29. Ivey JK (2004) What do parents expect? A study of likelihood and importance issues for children with autism spectrum disorders. Focus on Autism and Other Developmental Disabilities 19: 27-33.

30. Kahriman İ, Bayat M (2008) Özürlü çocuğa sahip ebeveynlerin yaşadiklari güçlükler ve algiladiklari sosyal destek düzeyleri. Öz-Veri Dergisi 5. 